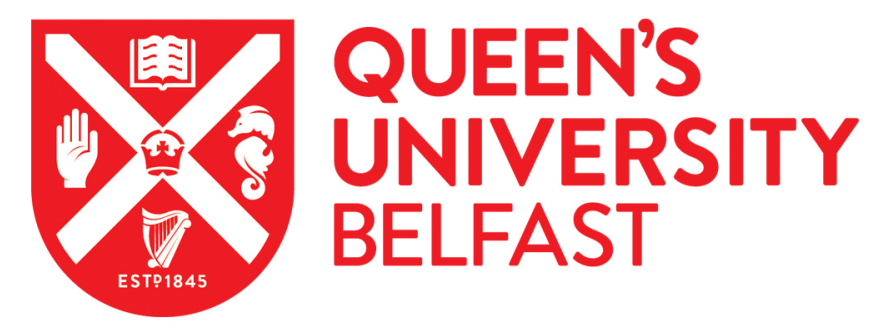

\title{
Increasingly 'Irrational' Party Systems: Evidence that There Are Increasingly More Than Two at the District level
}

Raymond, C. D. (2013). Increasingly 'Irrational' Party Systems: Evidence that There Are Increasingly More Than Two at the District level. Government and Opposition, 48(4), 506-525. https://doi.org/10.1017/gov.2013.5

\author{
Published in: \\ Government and Opposition
}

Document Version:

Peer reviewed version

Queen's University Belfast - Research Portal:

Link to publication record in Queen's University Belfast Research Portal

Publisher rights

Copyright The Author 2013. Published by Government and Opposition Limited and Cambridge University Press

\section{General rights}

Copyright for the publications made accessible via the Queen's University Belfast Research Portal is retained by the author(s) and / or other copyright owners and it is a condition of accessing these publications that users recognise and abide by the legal requirements associated with these rights.

Take down policy

The Research Portal is Queen's institutional repository that provides access to Queen's research output. Every effort has been made to ensure that content in the Research Portal does not infringe any person's rights, or applicable UK laws. If you discover content in the Research Portal that you believe breaches copyright or violates any law, please contact openaccess@qub.ac.uk. 
Increasingly 'irrational’ party systems: Evidence that the number of parties increasingly exceeds two at the district level

Forthcoming in Government and Opposition

\author{
Christopher D. Raymond \\ University of New Orleans \\ cdraymon@uno.edu
}

\begin{abstract}
Recent work has noted an increase in the number of parties at the national level in both proportional and majoritarian electoral systems. While the conventional wisdom maintains that the incentives provided by the electoral system will prevent the number of parties at the district level from exceeding two in majoritarian systems, the evidence presented here demonstrates otherwise. I argue that this has occurred because the number of cleavages articulated by parties has increased as several third parties have begun articulating cleavages that are not wellrepresented by the two larger parties.
\end{abstract}


Recent work by Robin Best notes a divergence at the national level in the number of parties winning legislative representation and the number of parties competing for and winning votes. ${ }^{1}$ In both majoritarian and proportional systems, the number of parties winning votes has increased since the Second World War. However, the number of parties winning seats in majoritarian systems has remained closer to two than in proportional systems, where the number of parties winning seats has increased in relative proportion to the number of parties winning votes.

Best notes the possibility that the discrepancy in majoritarian systems between the number of parties winning seats and the far greater number of parties winning votes reflects 'increasing irrationality' on the part of voters in these systems, with voters knowingly supporting parties without any chance of winning representation. However, it remains to be seen whether this is the case. It could be that these national-level results appear 'irrational' only in the aggregate, while at the district and individual levels, voters may still conform to the two-party expectations of strategic voting theory. As Gary Cox notes, parties may encounter 'coordination failures' (which refer to the inability of parties to compete effectively across all districts) that lead to their total replacement by a locally-strong third party at the district level, thereby leaving only two parties competing in each district while competition at the national level features more than two parties. ${ }^{2}$

This paper probes these issues further. Specifically, it looks at the number of parties competing for and winning votes at the district level in order to determine whether the number of parties conforms to the two-party expectations consistent with strategic voting theory, or whether voters are displaying patterns of 'increasing irrationality' and supporting multiparty competition at the district level. The results are important because they speak to the larger debate between 
the two major explanations for the number of parties observed cross-nationally. One explanation — the institutional approach—maintains that the number of parties is determined by the proportionality of the electoral system, predicting that the number of parties in each district will converge on two in countries operating under first-past-the-post (FPTP). The other explanation — the social cleavage approach—maintains that the number of parties is determined by the number of cleavages; as the number of cleavages increases, the number of parties increases. Should the number of parties converge on two, this would demonstrate that the institutional approach remains valid despite the national-level evidence of increasing party system size presented by Best. However, should the number of parties exceed two at the district level, this would provide evidence in favour of the social cleavage approach.

To preview the findings, this paper demonstrates that the number of parties choosing to contest elections and winning votes increasingly exceeds two-party predictions in three countries operating under FPTP: Canada, the United Kingdom, and New Zealand (prior to 1993). In order to explain these findings, I develop an explanation that is rooted in the social cleavage approach. The number of parties has increased in these countries as the number of cleavages articulated by party elites has increased. Third parties have pursued strategies that are irrational according to the strategic voting literature, competing in most districts in order to represent groups of voters who are present to some degree in every district and who are not well-represented by the existing parties.

\section{Electoral Systems, Strategic Voting, and Coordination Failures}

The conventional wisdom maintains that the number of parties observed cross-nationally owes much to the proportionality of the electoral system. Following the seminal work by Duverger, ${ }^{3}$ this literature holds that the number of parties tends toward two in countries using 
FPTP, while multiparty systems tend to be found in countries using proportional representation (PR) electoral systems. Duverger posited two reasons for why this occurs. One is the mechanical effect of electoral systems, or how votes are translated into seats: FPTP systems tend to produce more disproportional seats-votes ratios, while PR systems tend to produce seat shares that more proportionally reflect parties' vote shares. ${ }^{4}$ The other and perhaps more powerful effect is psychological. Anticipating the mechanical effect, voters will strategically desert their most-preferred candidates in favour of less-preferred candidates if they anticipate that votes for their most-preferred candidates will be wasted (and possibly resulting in victory for their leastpreferred candidates). For their part, parties will forgo expenditures on districts they do not expect to win. ${ }^{5}$ The prediction that strategic voting will produce two-party convergence has been (re-)affirmed by a number of works. ${ }^{6}$ Because only one candidate is elected per district, the psychological effect should be strongest in FPTP systems, diminishing as district magnitude increases.

A considerable body of evidence has been amassed demonstrating this strategic voting phenomenon among voters. ${ }^{7}$ Examining the system-level consequences of strategic voting, numerous studies have found that the number of parties is greater in countries operating under PR than majoritarian systems like FPTP. ${ }^{8}$ While most studies focus on the number of parties at the national level, the psychological effect applies most clearly at the district level. As Cox has noted, the number of parties competing at the national level may exceed two, yet the number of parties competing in any one district may still conform to the predictions of strategic voting theory and remain at (or below) two. ${ }^{9}$ Referring to coordination failures, Cox notes that one of the two major parties may strategically exit a district in which a third party with locally-strong 
support—support that makes the party more competitive than the two major parties—also contests that district.

Although evidence examining the number of parties at the district level has found that the institutional effects apply at the district level much like they do at the national level, ${ }^{10}$ other studies have found that district-level party systems exceed the two-party predictions made by the institutional approach. Examining the case of Canada, Brian Gaines noted that the number of parties competing at the district level exceeded two throughout most of the twentieth century. ${ }^{11}$ Gaines found similar evidence when looking at the United Kingdom in the period following the 1960s. ${ }^{12}$ Others have found that the number of parties at the district level often exceeds two in India, where the number of parties appears to be impacted significantly by the choices made by party elites to contest or not contest certain districts. ${ }^{13}$ Thus, while the institutional approach predicts that the number of parties competing in any one district in countries operating under FPTP should not exceed two, there is reason to believe that the number of parties at the district level exceeds two much like Best has noted with regard to national-level party systems. Elite Agency and the Social Cleavage Approach

The major alternative explanation maintains that the number of parties is determined more by the number of social cleavages than the proportionality of the electoral system. ${ }^{14}$ Because parties emerge to represent the interests of particular social groups to the exclusion of others, increases in the number of cleavages place strains on the existing parties' ability to represent these new groups of voters. This can be seen early in the twentieth century with the extension of universal (male) suffrage, which incorporated working-class voters who were essential to the fortunes of socialist and labour parties targeting their support (and difficult for the existing liberal and conservative parties to represent credibly). ${ }^{15}$ More recently, the 
emergence of postmaterial voters has put pressure upon the existing parties either to adapt to represent this new base of voters and risk alienating their existing bases of support, or to risk losing this potential base of voters to another (third) party. ${ }^{16}$ Given these challenges of representation, the number of parties may increase as the number of cleavages present in a given district increases, despite the incentives of the electoral system.

While much of the early work in this tradition assumed that the articulation of cleavages by party elites would be automatic, a growing body of literature suggests that elites have considerable agency in determining which cleavages to articulate. ${ }^{17}$ The interplay of social cleavages and elite articulation can be seen with regard to the evolution of party competition in the nineteenth and early twentieth centuries. Caramani notes that the emergence of competitive elections was determined by the decisions taken by party elites to represent certain cleavages over others. ${ }^{18}$ As the incentives for controlling the machinery of government became more alluring, parties chose to de-emphasise the issues associated with the territorial (urban-rural, regional, etc.) cleavages they had traditionally represented in favour of issues related to functional (class, religious, etc.) cleavages that were present across most districts. This choice allowed them to compete effectively for votes in most districts (thus improving their chances of winning a majority of seats). While this understanding of cleavage articulation differs from definitions found in some of the most prominent works (e.g. Bartolini and Mair), it corresponds with more recent definitions of the term cleavage in ways that retain the focus on parties' representation of issues associated with certain social groups to the exclusion of others, while recognising the considerable agency possessed by party actors in deciding which issues to articulate and which groups to represent. ${ }^{19}$ 
This agency may impact the number of parties. For instance, because parties represent certain groups to the exclusion of others, the major parties may choose not to articulate cleavages that do not fit well with their existing bases of support, particularly if these parties are already able to control the machinery of government with their existing bases of support (as has been the case with the two largest parties in each country operating under FPTP examined below). Additionally, if third parties do not articulate issues associated with these cleavages, the wouldbe support for these third parties either goes to the existing parties (or these voters fail to turn out); if third parties do choose to articulate issues associated with these new cleavages, the number of parties will increase beyond two.

In sum, the literature rooted in the social cleavage approach provides an explanation for why the increasing size of Western party systems observed by Best at the national level may be mirrored at the district level. If the number of parties competing for and winning votes at the district level converges on two, this would provide evidence in favour of the institutional approach. If the number of parties exceeds two, particularly if sustained over an extended period, this would provide evidence in favour of the social cleavage approach.

\section{The Number of Parties Winning Votes}

Turning to the empirical evidence, this section examines whether the number of parties winning votes at the district level exceeds the two-party predictions made by the institutional approach in FPTP systems. There is need for additional research focusing directly upon FPTP systems. Previous research has concluded that institutional and social cleavage effects appear to interact with one another. ${ }^{20}$ However, while these studies help to explain differences in the number of parties at the same level of electoral system proportionality in PR systems, the interactive effects seen in these studies lead to the conclusion that the effects of social cleavages 
do not produce multiparty systems in FPTP systems. Consequently, these studies fail to explain why the number of parties might exceed two in FPTP systems. Thus, further study of FPTP systems is needed. To this end, the data in this study focus upon three countries operating under FPTP: Canada (covering the years from 1867-2011), the United Kingdom (from 1832-2010), and New Zealand (from 1905-1993, prior to the adoption of a mixed-member proportional system). ${ }^{21}$ Focusing on Canada and the United Kingdom (where previous research has found that the number of parties exceeds two) in addition to New Zealand (which has received little attention in previous research) allows one to examine whether the forces thought to be leading the number of parties to exceed two in Canada and the United Kingdom are also present in New Zealand.

Despite the small number of countries examined here, the findings from these cases are quite generalisable. Because these three countries have relied exclusively on the same FPTP electoral system throughout most of the period under study (particularly the period following the Second World War when the number of parties at the national level increased beyond two), ${ }^{22}$ the primary institutional effect argued to be associated with party system size — the proportionality of the electoral system—is held constant. As a result, any deviations from two-party predictions in these three countries would suggest that these processes are capable of occurring in more proportional systems, where the electoral system poses less of a barrier to new party entry. Additionally, while focusing solely on FPTP countries helps to minimize electoral system variance, these three countries do vary in terms of other variables thought to be necessary for the emergence of multiparty systems. Namely, these three cases allow me to examine what effects of federalism, party financing, and partisan dealignment have had on the number of parties. If district-level party systems in all three countries are exceed two-party predictions, then these additional variables cannot explain the emergence of multiparty systems at the district level. 
To measure the number of parties, I use the effective number of electoral parties (ENEP) ${ }^{23}$ While the institutional literature predicts that the number of parties will converge on two, few would accept the presence of third parties winning scant votes as evidence that is sufficiently contradictory of Duverger's law. Because ENEP discounts the number of parties by weighting each party according to its vote share (thus leaving only the 'effective' number of parties), ENEP provides a more conservative measure of the number of parties that is biased in favour of the predictions made by the institutional literature. Previous studies testing the predictions made by the institutional literature have made use of this measure for precisely the same reasons. ${ }^{24}$

Figure 1 displays the mean ENEP at the district level in each election. ${ }^{25}$ During the early period in each country's time series, mean district-level ENEP converges on two in each country. ${ }^{26}$ At several points, however, mean ENEP exceeds two; even allowing for some deviation from the two-party prediction by using a conservative measure of the number of parties like ENEP, the fact remains that the number of parties increasingly exceeds the two-party predictions made by the institutional literature. This occurs early in the time series in New Zealand (1919), but later converges on two from 1938-1954, before increasing consistently beyond two (beginning in 1954) until the end of the time series. In Canada, mean ENEP has not fallen below two since 1935, and often the number of constituencies with effectively two or fewer parties is less than 10 per cent. While mean ENEP converges on two between 1931 and 1959 in the United Kingdom, mean ENEP begins to exceed two between 1918 and 1929 and then even more significantly from 1974 on. The most consistent deviations from two-party predictions in each country occur following the Second World War, the same period in which Best finds that the number of parties exceeded two at the national level. These deviations from 
two-party predictions are sufficient to conclude that the number of parties at the district level exceeds the expectations of the institutional literature.

\section{Figure 1 about here}

Before proceeding further, one should note that these patterns rule out three other prominent explanations for district-level party systems in excess of two-party predictions. Several recent works argue that because issues differ at the federal and provincial levels, federalism may give rise to third parties with support bases in certain regions that allow them to compete successfully at the district level with the larger, more nationalised parties. ${ }^{27}$ However, the fact that Canada is the only federal system of the three countries examined here, paired with the fact that mean district-level ENEP exceeds two-party expectations in each country, demonstrates that federalism is not a necessary cause of multiparty systems. While Gaines has extended the multilevel elections concept to the United Kingdom, where European Parliament elections have added a federal-like component in the past few decades, ${ }^{28}$ the fact that New Zealand (which has no such second level of elections) exceeds two-party predictions provides further evidence that multilevel elections are not the driving force behind the party fractionalisation observed in these three countries.

Additionally, arguments rooted in party financing are insufficient explanations of multiparty systems in these three cases. With an increasing number of parties dependent upon the state for finance cross-nationally, ${ }^{29}$ government-subsidised campaign finance may provide third parties enough money to persist in the face of strategic desertion by voters and donors. However, the empirical record casts doubt on such arguments as explanations for why multiparty systems have emerged in FPTP systems. Johnston and Cutler note that while party subsidisation in Canada dates back to 1968 (though the most consequential campaign finance laws date back 
only to 2004), this may have been more a consequence rather than a cause of increased fractionalisation, as district-level ENEP exceeded two-party predictions throughout (and prior to) the 1960s. ${ }^{30}$ Additionally, the United Kingdom and New Zealand demonstrate that party subsidies alone cannot explain the increasing patterns of fractionalisation seen here because multiparty systems emerged at the district level in both countries despite the lack of subsidisation in the United Kingdom and before the advent of party subsidisation in New Zealand. ${ }^{31}$

Finally, these patterns are inconsistent with an explanation that stresses dealignment as the root cause of party fractionalization at the district level. Particularly regarding electoral competition since the 1970s, one interpretation of the dealignment literature would predict that as voters have become less attached to the parties and more issue oriented, ${ }^{32}$ third parties have benefitted and the number of parties increased beyond two. As one can see, however, mean ENEP exceeded two-party predictions in all three countries prior to the period of dealignment. While major-party dealignment likely improved the chances for third parties to appeal to voters dissatisfied with the two larger parties, the data presented here clearly show that dealignment was not necessary for the development of multiparty competition.

To summarize, the data presented here clearly show that the number of parties exceeds the two-party predictions made by the institutional approach for district-level races. While the data presented in this section do not decisively support the social cleavage approach, the fact that the patterns of party competition at the district level do not conform to the institutional approach and do not appear to conform to other explanations for deviations from two-party predictions provides tentative support. In the next section, I examine the emergence of some of the key third parties in each country to show more conclusively how the social cleavage approach is at work, leading the number of parties to exceed two at the district level. 
The Evolution of Multiparty Competition

Evidence in favour of the social cleavage approach can be seen when looking at the patterns of district contestation, particularly for some of the major third parties, over time. Specifically, I examine the proportion of districts contested by the major parties in each country, similar to Caramani, who notes that the nationalization of parties' electoral strategies and support reflects the types of cleavage groups targeted. ${ }^{33}$ Figures 2, 3, and 4 present the proportion of districts contested by the major parties in Canada, the United Kingdom, and New Zealand, respectively. Before proceeding to the country-specific analyses, one should note some general patterns. At the beginning of the time series in each country, the proportion of districts contested by each party is quite variable, ranging from highs around .9 for the Liberal Party in New Zealand to a low of .35 for the Canadian Liberals in 1867. Over time, the two largest parties in each country begin to contest nearly every district, consistent with the discussion in Carmani noting the evolution of competitive elections resulting from the decisions of elites to target more functional (instead of territorial) cleavages. ${ }^{34}$ During the period following the Second World War examined by Best, the two largest parties in each country contest nearly every district. By as early as 1954 and as late as 1974, the major third party examined in each country also contests the same proportion of districts as the two largest parties.

\section{Figures 2-4 about here}

Closer examination of each country explains why third parties began to contest the same proportion of districts as the two larger parties. Beginning with the Canadian case in Figure 2, arguably the most important third party in Canadian politics began competing with both the Liberal and Conservative parties in most districts shortly after its inception. The Cooperative Commonwealth Federation (or CCF, later to be renamed the New Democratic Party, or NDP, in 
1962) emerged in 1935 contesting over 40 per cent of the total number of districts, and by 1949 was competing in over 80 per cent. It is interesting to note that prior to the emergence of the CCF in 1935, mean district-level ENEP was just over two; since then, mean district ENEP has rarely fallen below $2.5 .^{35}$ The incentive to contest most, if not all, districts originated in the fact that the party has appealed to working class voters (and others sympathetic to the party's socialdemocratic appeals) in all professions, voters who are present to some degree in every district. ${ }^{36}$ To borrow Caramani's language, the CCF/NDP appeals to a functional cleavage that the two larger parties have chosen not to articulate, ${ }^{37}$ leaving this sizable base of voters open to the CCF/NDP's social-democratic appeals. Unlike the major third party preceding the CCF/NDPthe Progressive party, which appealed primarily to Western agricultural interests and only secondarily to those in manufacturing ${ }^{38}$ — the CCF/NDP has consciously chosen to appeal to working-class voters in all occupations so as not to face the same fate as the short-lived Progressive party.

The evolution of multiparty competition in the United Kingdom occurs in two distinct periods, as seen in Figure 3. The first occurs between 1918 and 1929, when all three partiesConservative, Liberal, and Labour — competed in nearly every district. The gradual emergence of the Labour party between 1900 and 1918 immediately preceded the slow decay of the Liberal party, whose bases of support had begun to shrink as the cleavage between Conformist and NonConformist voters had likewise begun to decline. ${ }^{39}$ By 1931, the Liberal party was ultimately displaced by Labour as one of the two largest parties, and the Liberals entered a long period of decline, contesting fewer seats (for instance, losing all but nine of the party's candidate deposits despite the large proportion of contested seats in 1950). However, the party slowly began to recover its stake in elections so that the party was able to contest 90 per cent or more of the 
districts from 1974 on. Such a strategy is in keeping with the party's decision to target educated middle-class voters, particularly those with postmaterial values, ${ }^{40}$ who find both the Labour and Conservative parties unacceptable. ${ }^{41}$ Because these voters are present to some degree in every district, the Liberals have contested most districts as they have chosen to articulate issues related to this functional cleavage. It is no coincidence that the sharp and lasting uptick in mean ENEP noted in Figure 1 (rising from 2.19 to 2.62 between 1970 and 1974) occurs at the same time as the Liberals (and later, the Liberal Democrats) begin catering to this functional cleavage and contesting nearly every district.

The patterns of party competition observed in New Zealand begin in quite dramatic fashion. While the Liberal (later United) party saw little organized opposition in 1905, the dramatic rise of Reform in 1908 ushered a brief period of two-party competition that evolved into three-party competition as the Labour party gradually emerged into a force strong enough to give incentive to the parties of the centre and right (United and Reform) to merge, forming the National party. ${ }^{42}$ As seen in Figure 1 above, these two parties effectively dominated elections as the number of parties converged on two from 1935-1951. This changed in the election of 1954 as the Social Credit Political League broke through, contesting nearly every seat and winning 11 per cent of the vote. Drawing support from small business owners, farmers, and family-oriented religious voters — whose concerns on issues of moral traditionalism and economic selfsufficiency were not well-represented by Labour or National ${ }^{43}$ — the party contested every district from 1957 until 1987 before the merging with several smaller third parties to form the Alliance in 1991. Although the party experienced some setbacks during these years, the party averaged nearly 10 per cent of the national vote during the period from 1954-1990, never polling below five per cent prior to 1990 and polling as high as 20 per cent in 1978. From its initial success in 
1954 until 1987, the presence of Social Credit in nearly every district is associated with districtlevel ENEP values significantly in excess of two. ${ }^{44}$

In sum, these figures show that the increases in district-level ENEP observed in Figure 1 coincide with increases in the proportions of districts contested by the major third party in each country. In keeping with the social cleavage approach, the fact that each third party has chosen to articulate and represent functional cleavages not represented by the existing parties reflects an increase in the number of cleavages in each country; in other words, the increases in district-level ENEP appear due to increases in the number of cleavages articulated by parties. Because each of the third parties has chosen to articulate functional cleavages—with voters belonging to these cleavages present to some degree in most districts - these parties have defied the expectations of strategic voting theory and contested nearly every district in order to represent their targeted base of voters.

\section{Conclusion}

Inspired by the findings presented in Best, noting that the number of parties competing for — and winning — votes at the national level in countries operating under FPTP increasingly exceeds two over the past several decades, this paper has sought to determine whether the same processes have occurred at the district level. While the institutional literature predicts that the number of parties should not exceed two at the district level even if the number of parties exceeds two nationally, ${ }^{45}$ the evidence presented here is more consistent with the social cleavage approach, which predicts that the number of parties may increase beyond two as the number of cleavages increases. Even if one allows for some deviation from two-party predictions, and even if one uses a measure of the number of parties that is biased in favour of the institutional 
approach, the fact remains that the number of parties increasingly deviates from two-party expectations.

Examining the patterns of party competition of the most important third parties behind the increases in the number of parties demonstrates that these parties are pursuing strategies that allow them to compete for voters belonging to the cleavages they represent, competing in nearly every district despite the fact that such strategies are 'irrational' according to strategic voting theory. Although the data presented here do not bring evidence to bear that directly measures variables associated with the social cleavage approach, previous studies have shown that patterns of party competition reflect the social-group bases of parties’ support; ${ }^{46}$ because each third party examined here represents issues and values that resonate with certain groups of voters more than others, and because the patterns of third party competition presented above match the findings of previous work, the conclusions reached here accord with previous literature.

While the evidence clearly shows that the number of parties exceeds the expectations of the institutional approach (and the strategic voting literature upon which this literature is based), the mechanisms preventing strategic voting incentives from limiting the number of parties to two in any one district are not fully understood. The strategic voting literature acknowledges several assumptions; without meeting these assumptions, strategic voting will not occur and the number of parties will exceed two. ${ }^{47}$ However, there is precious little research specifically examining whether the absence of these factors does indeed prevent strategic voting, let alone the frequency and degree to which these assumptions are met. ${ }^{48}$ Further research is needed to determine which of these assumptions is most crucial for two-party convergence, or whether other factors are preventing the emergence of multiparty competition, in order to understand why third parties like those examined here have not been strategically deserted by their supporters. 
Figure 1: Mean District-Level ENEP in Canada, New Zealand, and the United Kingdom

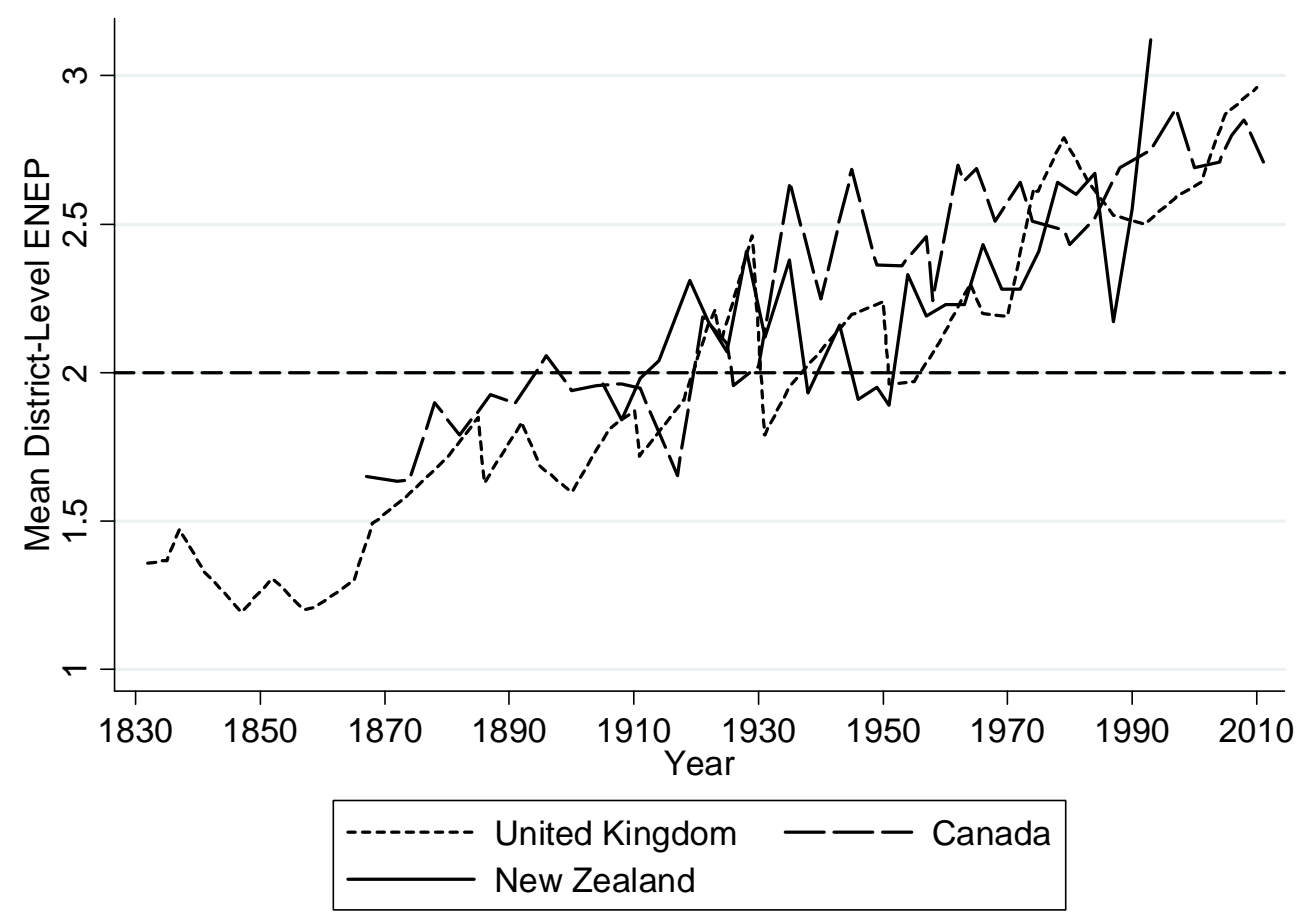

Note: single-member districts only. 
Figure 2: The Evolution of Party Competition in Canada

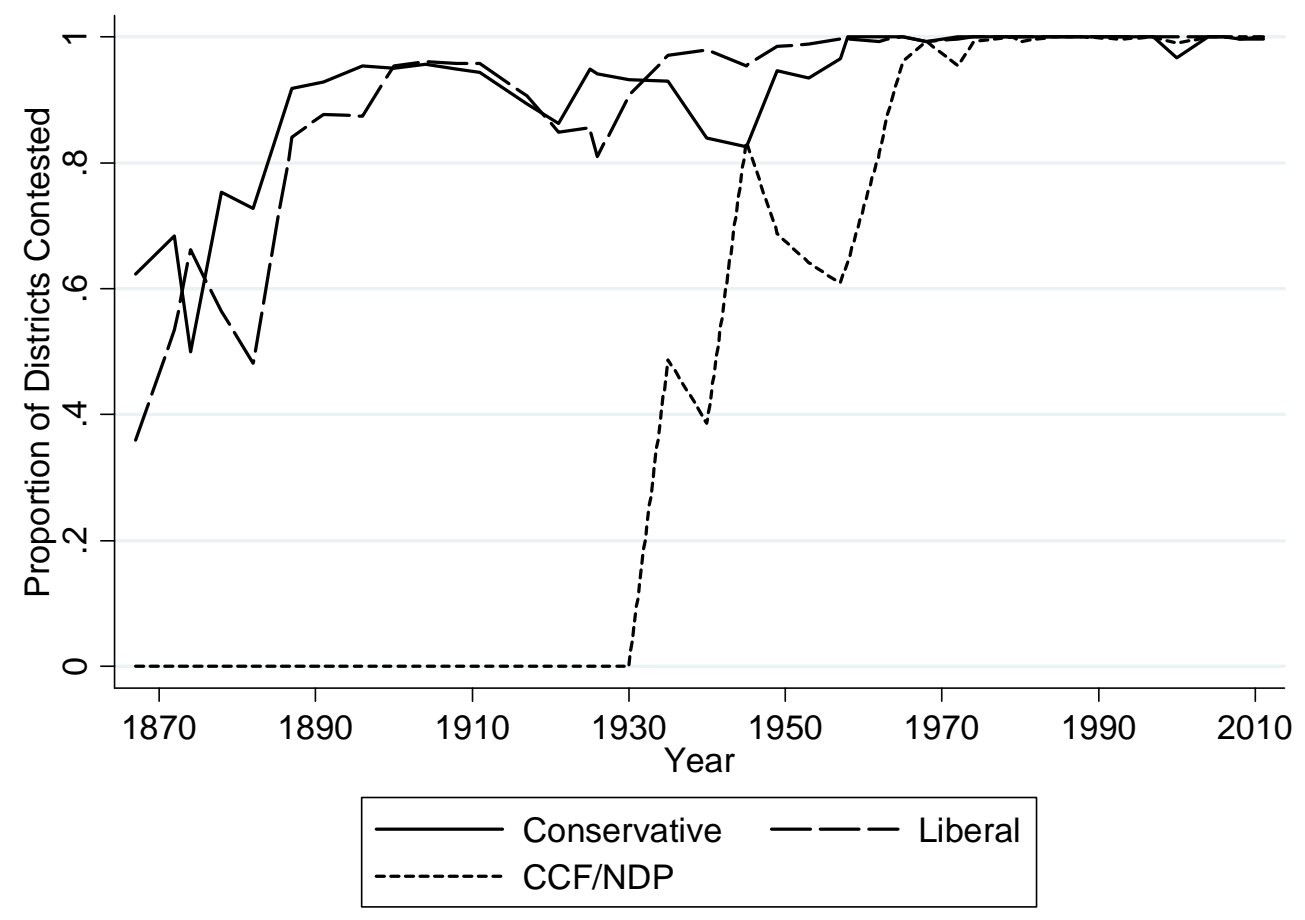

Note: single-member districts only. 
Figure 3: The Evolution of Party Competition in the United Kingdom

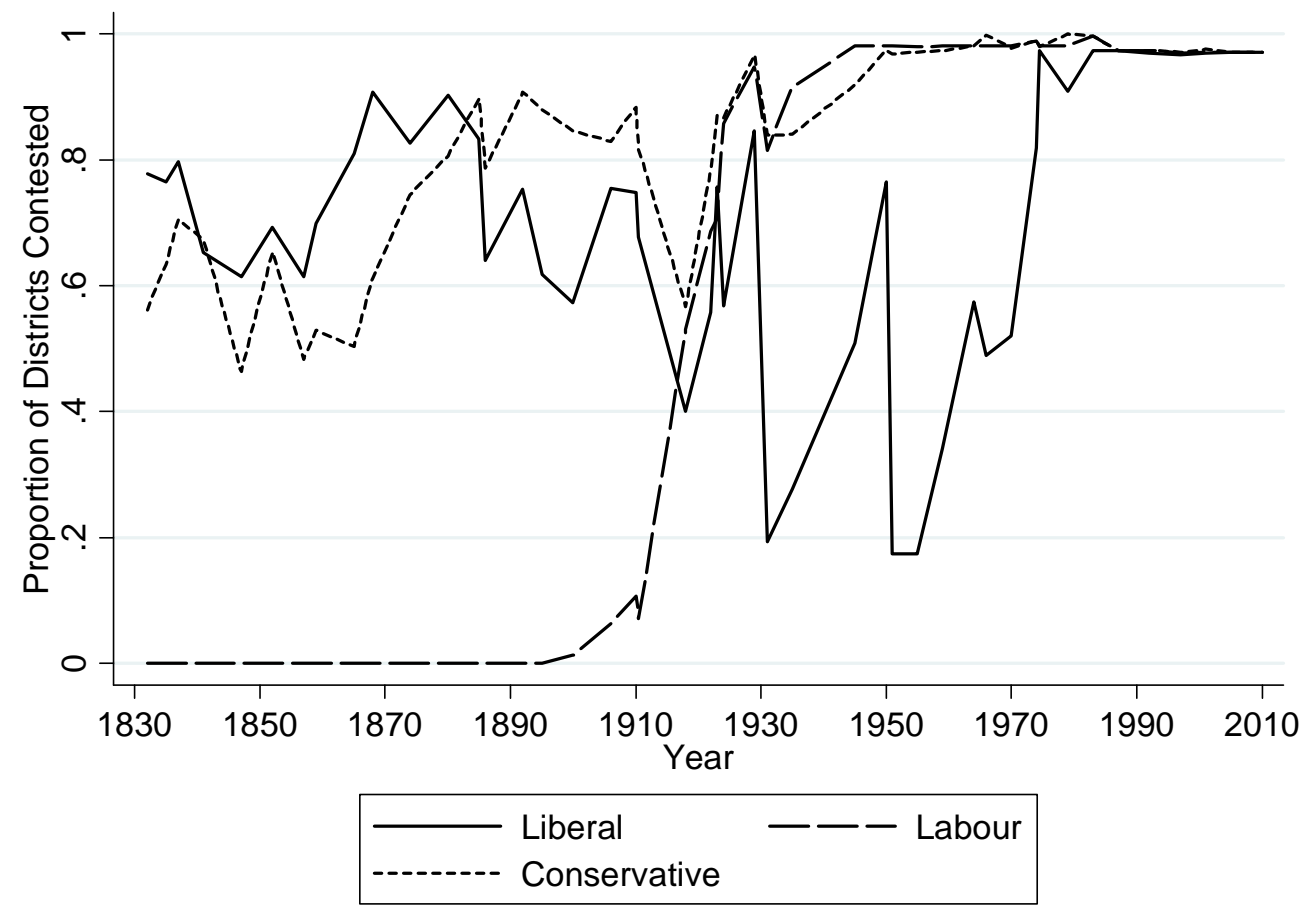

Note: single-member districts only. 
Figure 4: The Evolution of Party Competition in New Zealand

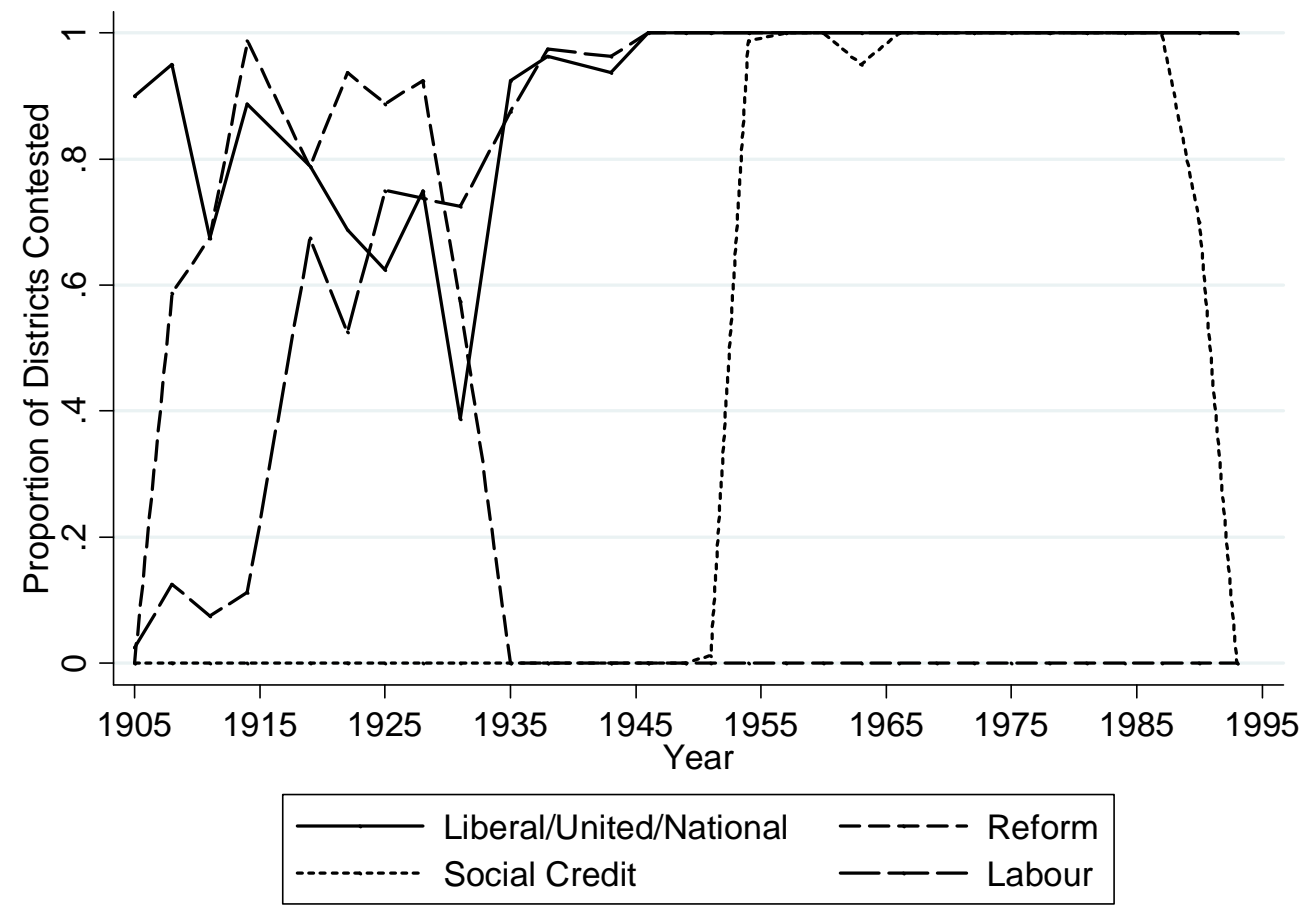




\footnotetext{
${ }^{1}$ Robin E. Best, 'Increasing irrationality? The equilibrium relationship between electoral and legislative party system size, 1950-2005’, Electoral Studies, 29: 1 (2010), pp. 105-116.

${ }^{2}$ Gary W. Cox, Making Votes Count: Strategic Coordination in the World's Electoral Systems, New York, Cambridge University Press, 1997; ibid, 'Electoral Rules and Electoral Coordination', Annual Review of Political Science, 2 (1999), pp. 145-161.

${ }^{3}$ Maurice Duverger, Political Parties. New York, Wiley, 1954.

${ }^{4}$ Douglas W. Rae, The Political Consequences of Electoral Laws, New Haven, Yale University Press, 1971; Michael, Gallagher, 'Proportionality, Disproportionality and Electoral Systems’, Electoral Studies, 10: 1 (1991), pp. 33-51; Arend Lijphart, Patterns of Democracy: Government Forms and Performance in Thirty-six Countries, New Haven, Yale University Press, 1999.

${ }^{5}$ Richard D, McKelvey and Peter Ordeshook, 'A General Theory of the Calculus of Voting', in J. F. Herndon and J. L. Bernd (eds.), Mathematical Applications in Political Science, vol. 6, Charlottesville, University Press of Virginia, 1972.
}

${ }^{6}$ Cox, Making Votes Count; Pradeep K. Chhibber and Ken Kollman, The formation of national party systems: Federalism and party competition in Canada, Great Britain, India, and the United States, Princeton, Princeton University Press, 2004

${ }^{7}$ David. J. Lanoue and Shaun Bowler, 'The Sources of Tactical Voting in British Parliamentary Elections, 19831987’, Political Behavior, 14: 2 (1992), pp. 141-157; Richard G. Niemi, Guy Whitten, and Mark N. Franklin, 'Constituency Characteristics, Individual Characteristics, and Tactical Voting in the 1987 British General Election', British Journal of Political Science, 23: 2 (1992), pp. 131-137; Cox, Making Votes Count; Jennifer L. Merolla and Laura B. Stephenson, 'Strategic Voting in Canada: A Cross Time Analysis', Electoral Studies, 26: 2 (2007), pp. 235-246.

${ }^{8}$ Rein Taagepera and Matthew Søberg Shugart, Seats and Votes: The Effects and Determinants of Electoral Systems, New Haven: Yale University Press, 1989; William Roberts Clark and Matt Golder, 'Rehabilitating Duverger's Theory: Testing the Mechanical and Strategic Modifying Effects of Electoral Laws', Comparative Political Studies, 39: 6 (2006), pp. 679-708; Rein Taagepera, Predicting party sizes: The logic of simple electoral systems, New York, Oxford University Press, 2007.

${ }^{9}$ Cox, Making Votes Count; ibid, 'Electoral Rules and Electoral Coordination'.

${ }^{10}$ Matthew M. Singer and Laura B. Stephenson, 'The Political Context and Duverger's Theory: Evidence at the District Level’, Electoral Studies, 28: 3 (2009), pp. 480-491.

${ }^{11}$ Brian J. Gaines, 'Duverger's Law and the Meaning of Canadian Exceptionalism', Comparative Political Studies, 32: 7 (1999), pp. 835-861; see also Richard Johnston and Fred Cutler, 'Canada: The Puzzle of Local Three-Party Competition', in Bernard Grofman, André Blais, and Shaun Bowler (eds.), Duverger's Law of Plurality Voting: The Logic of Party Competition in Canada, India, the United Kingdom, and the United States, New York, Springer, 2009, pp. 83-96.

12 Brian J. Gaines, 'Does the United Kingdom Obey Duverger's Law?’, in Bernard Grofman, André Blais, and Shaun Bowler (eds.), Duverger's Law of Plurality Voting: The Logic of Party Competition in Canada, India, the United Kingdom, and the United States, New York, Springer, 2009, pp. 115-134.

${ }^{13}$ Pradeep Chhibber and Geetha Murali, 'Duvergerian Dynamics in the Indian States: Federalism and the Number of Parties in the State Assembly Elections', Party Politics, 12: 1 (2006), pp. 5-34; see also Rekha Diwakar, 'Duverger's Law and the Size of the Indian Party System', Party Politics, 13: 5 (2007), pp. 539-561.

${ }^{14}$ Seymour Martin Lipset and Stein Rokkan (eds.), Party Systems and Voter Alignments: Cross-National Perspectives, New York, Free Press, 1967; Stein Rokkan, Stein, Citizens, Elections, and Parties, New York, Universitetsforlaget-McKay, 1970; Stefano Bartolini and Peter Mair, Identity, Competition and Electoral Availability: The Stabilisation of European Electorates 1885-1985, New York, Cambridge University Press, 1990.

${ }^{15}$ Lipset and Rokkan, Party Systems and Voter Alignments; Rokkan, Citizens, Elections, and Parties.

${ }^{16}$ Ronald Inglehart, The Silent Revolution: Changing Values and Political Styles Among Western Publics, Princeton, Princeton University Press, 1977; ibid, Culture Shift in Advanced Industrial Society, Princeton, Princeton University Press, 1990.

${ }^{17}$ Giovanni Sartori, 'From the Sociology of Politics to Political Sociology', in Seymour Martin Lipset (ed.), Politics and the Social Sciences, New York, Oxford University Press, 1969, pp. 65-100; Adam Przeworski and John Sprague, Paper Stones: A History of Electoral Socialism, Chicago, University of Chicago Press, 1986; Mariano Torcal and Scott Mainwaring, 'The Political Recrafting of Social Bases of Party Competition: Chile, 1973-95', 
British Journal of Political Science, 33: 1 (2003), pp. 55-84; Zsolt Enyedi, 'The Role of Agency in Cleavage Formation’, European Journal of Political Research, 44: 5 (2005), pp. 697-720.

${ }^{18}$ Daniele Caramani, 'The End of Silent Elections: The Birth of Electoral Competition, 1832-1915', Party Politics, 9: 4 (2003), pp. 411-433; ibid, The Nationalization of Politics: The Formation of National Electorates and Party Systems in Western Europe, New York, Cambridge University Press, 2004; ibid, 'The Formation of National Party Systems in Europe: A Comparative Historical Analysis’, Scandinavian Political Studies, 28: 4 (2005), pp. $295-322$.

${ }^{19}$ Zsolt Enyedi, 'The Social and Attitudinal Bases of Political Parties: Cleavage Politics Revisited', European Review, 16: 3 (2008), pp. 287-304.

${ }^{20}$ See, e.g., Peter C. Ordeshook and Olga V. Shvetsova, 'Ethnic Heterogeneity, District Magnitude, and the Number of Parties', American Journal of Political Science, 38: 1 (1994), pp. 100-123’; Clark and Golder, 'Rehabilitating Duverger's Theory'; Singer and Stephenson, 'The Political Context and Duverger's Theory’.

${ }^{21}$ The data for the United Kingdom through the 1997 elections were obtained from Daniele Caramani, Elections in Western Europe since 1815: Electoral Results by Constituencies, New York, Palgrave, 2000. Data for New Zealand until 1993 were taken from the New Zealand Election Study website (www.nzes.org). All other data were collected from each country's respective election websites.

${ }^{22}$ Canada and the United Kingdom employed multimember districts early in each country's history; in Canada, the use of two-member districts had disappeared in all but two districts by 1935, while the use of multimember districts in the United Kingdom was discontinued completely by 1950. For the purposes of testing the prediction of twoparty convergence in FPTP elections, only single-member districts are examined here, though the inclusion of multimember districts does not significantly affect the findings presented here. One should also note that New Zealand employed a two-round majority electoral system in the elections of 1908 and 1911.

${ }^{23}$ Markku Laakso and Rein Taagepera, “"Effective” Number of Parties: A Measure with Application to West Europe', Comparative Political Studies, 12: 1 (1979), pp. 3-27.

${ }^{24}$ See, e.g., Cox, Making Votes Count; Taagepera, Predicting party sizes; Singer and Stephenson, 'The Political Context and Duverger's Theory'.

${ }^{25}$ Several coding issues, though minor, merit discussion. First, when multiple candidates belonging to the same party contest a district, their votes are treated as one party when calculating ENEP; this biases the number of parties downward, in favour of the institutional approach. Second, in the case of uncontested districts, these are treated as having ENEP values of one to reflect the uncompetitive nature of these elections. Third, some candidates' party affiliations could not be found in some elections, particularly those occurring early in the time series in Canada. These candidates are treated as belonging to a party that is separate from independents, even though many of these candidates do not contest districts with independent candidacies. Finally, many independent partisans (e.g. Independent Conservative) contest elections early on in the time series of all three countries. Because these candidates ran independently from their parties, they are treated as separate parties.

${ }^{26}$ The results are nearly identical when using median ENEP, though the values are much lower-converging on one —in the United Kingdom during the period from 1841-1865.

${ }^{27}$ Pradeep K. Chhibber and Ken Kolman, 'Party Aggregation and the Number of Parties in India and the United States’, American Political Science Review, 92: 2 (1998), pp. 329-342; ibid, The formation of national party systems; Gaines, 'Duverger's Law and the Meaning of Canadian Exceptionalism'.

${ }^{28}$ Gaines, 'Does the United Kingdom Obey Duverger's Law?'.

${ }^{29}$ Richard S. Katz and Peter Mair, 'Changing Models of Party Organization and Party Democracy: the Emergence of the Cartel Party', Party Politics, 1: 1 (1995), pp. 5-28; Ingrid van Biezen and Petr Kopecký, 'The State and the Parties: Public Funding, Public Regulation, and Rent-Seeking in Contemporary Democracies', Party Politics, 13: 2 (2007), pp. 235-254.

30 Johnston and Cutler, 'Canada: The Puzzle of Local Three-Party Competition'.

${ }^{31}$ New Zealand did not begin to subsidise parties until the Electoral Finance Act 2007.

${ }^{32}$ Russell J. Dalton, 'Cognitive Mobilization and Partisan Dealignment in Advanced Industrial Democracies', Journal of Politics, 46: 1 (1984), pp. 264-284; Russell J. Dalton, Scott Flanagan, and Paul Beck (eds.), Electoral Change in Advanced Industrial Democracies, Princeton, Princeton University Press, 1984; Russell J. Dalton and Martin P. Wattenberg (eds.), Parties without Partisans: Political Change in Advanced Industrial Democracies, New York, Oxford University Press, 2000.

${ }^{33}$ Caramani, The Nationalization of Politics; ibid, 'The Formation of National Party Systems in Europe'.

${ }^{34}$ Caramani, 'The End of Silent Elections'. 
${ }^{35}$ While ENEP falls between 1962 and 1980, this is due in large part to the collapse of Social Credit, which endured a rupture between its Western Anglophone and Quebec-centred Francophone bases that crippled the party’s organization.

${ }^{36}$ For evidence of the party's working-class appeal, see Frederick C. Engelmann and Mildrid A. Schwartz, Political Parties and the Canadian Social Structure, Scarborough, ON, Prentice-Hall, 1967; Harold D. Clarke, Lawrence LeDuc, Jane Jensen, and Jon H. Pammet, Political Choice in Canada, New York, McGraw-Hill Ryerson Ltd., 1979; Elisabeth Gidengil, André Blais, Joanna Everitt, Partick Fournier, and Neil Nevitte, 'Back to the Future? Making Sense of the 2004 Election outside Quebec', Canadian Journal of Political Science, 39: 1 (2006), pp. 1-25.

${ }^{37}$ Historically and today, Conservatives tend to fare better among Protestant and Anglophone voters, whilst Liberals fare better among Catholic and Francophone voters; while these patterns used to reflect a more denominational divide, today these overlapping cleavages reflect the salience of ethno-linguistic issues. See Gidengil et al., 'Back to the Future?'.

${ }^{38}$ Paul F. Sharp, The Agrarian Revolt in Western Canada, Minneapolis, University of Minnesota Press, 1948; W. L. Morton, The Progressive Party in Canada, Toronto, University of Toronto Press, 1950.

${ }^{39}$ Trevor Wilson, The Downfall of the Liberal Party, 1914-1935, Ithaca, Cornell University Press, 1966; H. C. G. Matthew, R. I. McKibbin, and John A. Kay, 'The Franchise Factor in the Rise of the Labour Party', English Historical Review, 91: 361 (1976), pp. 723-752.

${ }^{40}$ Geoffrey Evans, Anthony Heath, and Mansur Lalljee, 'Measuring Left-Right and Libertarian-Authoritarian Values in the British Electorate', British Journal of Sociology, 47: 1 (1996), pp. 93-112.

${ }^{41}$ Anthony Heath, Roger Jowell, and John Curtice, How Britain Votes, New York, Pergamon Press, 1985; Richard Rose and Ian McAllister, The Loyalties of Voters: A Lifetime Learning Model, London, Sage, 1990.

${ }^{42}$ In the elections of 1931, United and Reform competed as separate parties, yet coordinated their election strategies in such a way that I treat them as being one party.

${ }^{43}$ Colin C. James, 'Social Credit and the Values Party', in Howard R. Penniman (ed.), New Zealand at the Polls: The General Election of 1978, Washington, D.C., American Enterprise Institute for Public Policy Research, 1980, pp. 148-167; Raymond Miller, Party Politics in New Zealand, New York, Oxford University Press, 2005.

${ }^{44}$ While other third parties like the Values Party (1972-1984) and New Zealand Party (1984) contributed to the ebbs and flows in mean district-level ENEP during this period, the district-level values of ENEP in excess of two throughout this period are explained largely by the presence of Social Credit.

${ }^{45}$ Cox, Making Votes Count; ibid, 'Electoral Rules and Electoral Coordination'.

${ }^{46}$ Caramani, 'The End of Silent Elections'; ibid, The Nationalization of Politics.

${ }^{47}$ Cox (Making Votes Count, pp 79) notes that voters (and party elites) may not behave strategically if they: (1) are not short-term instrumentally rational (e.g. they believe that surviving to compete in the next election may elevate the party's chances of winning in subsequent elections), (2) lack public information about voter preferences, and (3) care intensely about their first preferences (e.g. they hold a party identification) and/or are indifferent between their second and lower preferences.

${ }^{48}$ There has been some work looking at the effect of the second (information) assumption: see e.g. André Blais and Mathieu Turgeon, 'How good are voters at sorting out the weakest candidate in their constituency?', Electoral Studies, 23: 3 (2004), pp. 455-461; Michael F. Meffert, Sascha Huber, Thomas Gschwend, and Franz Urban Pappi, 'More than wishful thinking: Causes and consequences of voters' electoral expectations about parties and coalitions', Electoral Studies, 30: 4 (2011), pp. 804-815. However, few works have examined whether individuals' levels of information affect vote choices in comparison with the other assumptions required for strategic voting. 